\title{
26. CONTENT, COMPOSITION, AND THERMAL HISTORY OF ORGANIC MATTER IN MESOZOIC SEDIMENTS, FALKLAND PLATEAU
}

\author{
J.B. Comer, Department of Earth Sciences, The University of Tulsa, Tulsa, Oklahoma \\ and \\ R. Littlejohn, Amoco Production Company, Tulsa, Oklahoma
}

\section{INTRODUCTION}

Ten samples from DSDP Leg 36, Site 330 and Hole $327 \mathrm{~A}$, on the Falkland Plateau have been analyzed for organic matter content and maturity (Figure 1). Nine samples are from a thick, relatively uniform black shale of Mesozoic age which is described as sapropelic claystone by the DSDP Scientific Staff (1974). The other sample is from an older Mesozoic rock unit occurring at Site 330 which consists of interbedded clayey siltstone, sandstone, and limestone containing terrigenous plant debris (DSDP Scientific Staff, 1974).

Geochemical analyses were performed to determine whether the black shales could be a source for commercial hydrocarbon deposits. In addition, the thermal history of the organic matter as determined by palynomorph translucency and elemental composition was examined for its implications about the tectonic history of the region.

\section{HYDROCARBON GENERATING CAPABILITY}

Nonextractable organic carbon concentrations range between $0.7-5.1 \mathrm{wt} \%$ (Table 1). The organic carbon content of the sapropelic claystone averages $2.5 \mathrm{wt} \%$ which is well above the average value (1.4 wt \%) reported for shales in petroliferous areas (Trask and Patnode, 1942; Ronov, 1958). Only one sample from the interbedded unit below the sapropelic claystone was analyzed (C-1043), and it was found to contain $5.1 \mathrm{wt} \%$ organic C (Table 1).

All the samples have total bitumen $\left(\mathrm{C}_{15}+\right)$ /total organic carbon ratios of 0.02 or less (Table 1), suggesting that little of the liquid hydrocarbon generating potential of these samples has been realized. Aliphatic hydrocarbons constitute less than $50 \%$ of the total bitumen (Table 1). Gas chromatographic analysis indicates that the aliphatic fraction contains only a small proportion of normal paraffins (Figure 2). Urea adduction of one sample (C-1043) recovered less than $10 \%$ of the aliphatic fraction as normal paraffins, and these paraffins had a very strong odd-carbon predominance (Figure 2). The small quantity and strong oddcarbon predominance of the normal paraffins suggest that the organic-rich sediments are immature with respect to the thermal generation of liquid hydrocarbons (Bray and Evans, 1961).

Normalized carbon percentages based on $\mathrm{C}, \mathrm{H}, \mathrm{O}$, and $\mathrm{N}$ analyses of the isolated kerogens vary from $72.2 \%$ to $77.3 \%$, and the translucency of the palynomorphs Classopollis and Callialasporites ranges from

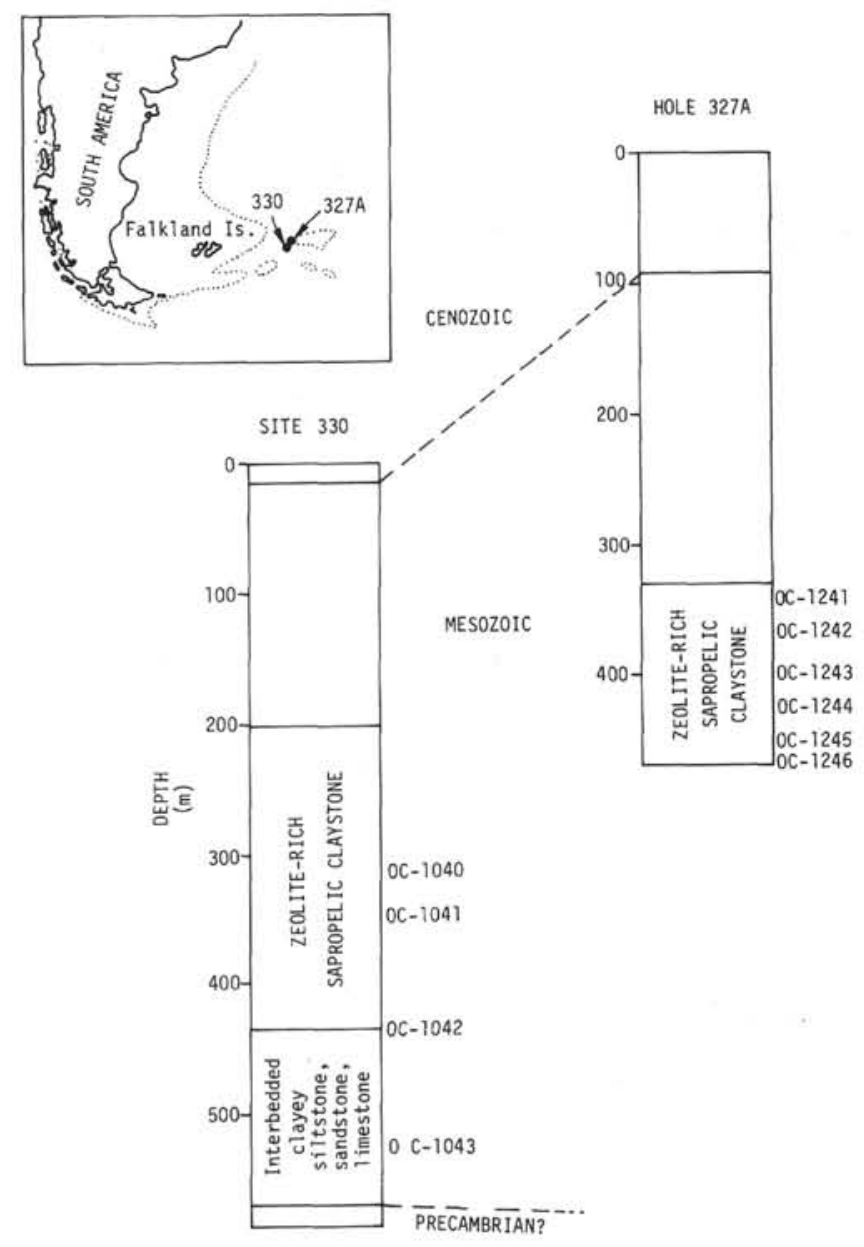

Figure 1. Stratigraphy and sample location map, Site 330 and Hole 327A. Stratigraphic datum is mean sea level.

$41 \%$ to $57 \%$ (Table 2). Intense hydrocarbon generation appears to begin with continued thermal stress after the kerogen has become relatively enriched in carbon above the $74 \%-76 \%$ level (LaPlante, 1974) and after the translucency of palynomorphs falls below $40 \%^{1}$ (Grayson, 1975, p. 271). Thus, the observed elemental and translucency data are further evidence of thermal immaturity of the organic matter in these sediments relative to hydrocarbon generation.

\footnotetext{
'Based on the pollen taxon Carya.
} 
TABLE 1

Organic Carbon and Bitumen Content

\begin{tabular}{|c|c|c|c|c|c|c|}
\hline Sample & $\begin{array}{c}\text { Depth } \\
\text { (m) }\end{array}$ & $\begin{array}{c}\text { Nonextractable } \\
\text { Organic Carbon } \\
\text { (wt \%) }\end{array}$ & $\begin{array}{c}\text { Total } \\
\text { Bitumen } \\
(\mathrm{mg} / 100 \mathrm{~g})^{\mathrm{a}}\end{array}$ & $\begin{array}{c}\text { Aliphatic } \\
\text { Hydrocarbons } \\
\text { (mg/100g) }\end{array}$ & $\begin{array}{l}\text { Aliphatic } \\
\text { Total } \\
\text { Bitumen }\end{array}$ & $\begin{array}{c}\text { Total } \\
\text { Bitumen } \\
\text { Total } \\
\text { Organic } \\
\text { Carbon }\end{array}$ \\
\hline \multicolumn{7}{|l|}{ Site 330} \\
\hline $\begin{array}{l}\text { C-1040 } \\
\text { C- } 1041 \\
\text { C-1042 } \\
\text { C-1043 }\end{array}$ & $\begin{array}{l}315 \\
352 \\
440 \\
525\end{array}$ & $\begin{array}{l}2.2 \\
2.9 \\
3.0 \\
5.1\end{array}$ & $\begin{array}{r}25.3 \\
25.0 \\
24.8 \\
111.4\end{array}$ & $\begin{array}{r}9.1 \\
8.8 \\
11.4 \\
36.0\end{array}$ & $\begin{array}{l}0.36 \\
0.35 \\
0.46 \\
0.32\end{array}$ & $\begin{array}{r}0.01 \\
<0.01 \\
<0.01 \\
0.02\end{array}$ \\
\hline \multicolumn{7}{|c|}{ Hole $327 \mathrm{~A}$} \\
\hline $\begin{array}{l}\text { C-1241 } \\
\text { C-1242 } \\
\text { C-1243 } \\
\text { C-1244 } \\
\text { C-1245 } \\
\text { C- } 1246\end{array}$ & $\begin{array}{l}341 \\
368 \\
396 \\
426 \\
453 \\
463\end{array}$ & $\begin{array}{l}1.0 \\
0.7 \\
4.9 \\
3.6 \\
1.7 \\
3.3\end{array}$ & $\begin{array}{r}10.6 \\
5.9 \\
49.0 \\
53.3 \\
19.5 \\
41.1\end{array}$ & $\begin{array}{r}2.7 \\
1.9 \\
10.1 \\
10.2 \\
7.5 \\
8.5\end{array}$ & $\begin{array}{l}0.25 \\
0.32 \\
0.20 \\
0.19 \\
0.38 \\
0.20\end{array}$ & $\begin{array}{r}0.01 \\
<0.01 \\
<0.01 \\
0.01 \\
0.01 \\
0.01\end{array}$ \\
\hline
\end{tabular}

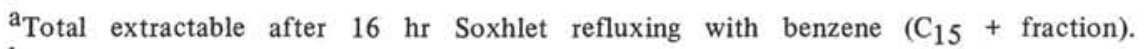

${ }^{\mathrm{b}}$ Heptane eluent passing through alumina-packed column.

A.

TOTAL ALIPHATIC FRACTION

$\times 3200$

$0.5 \mu \ell$
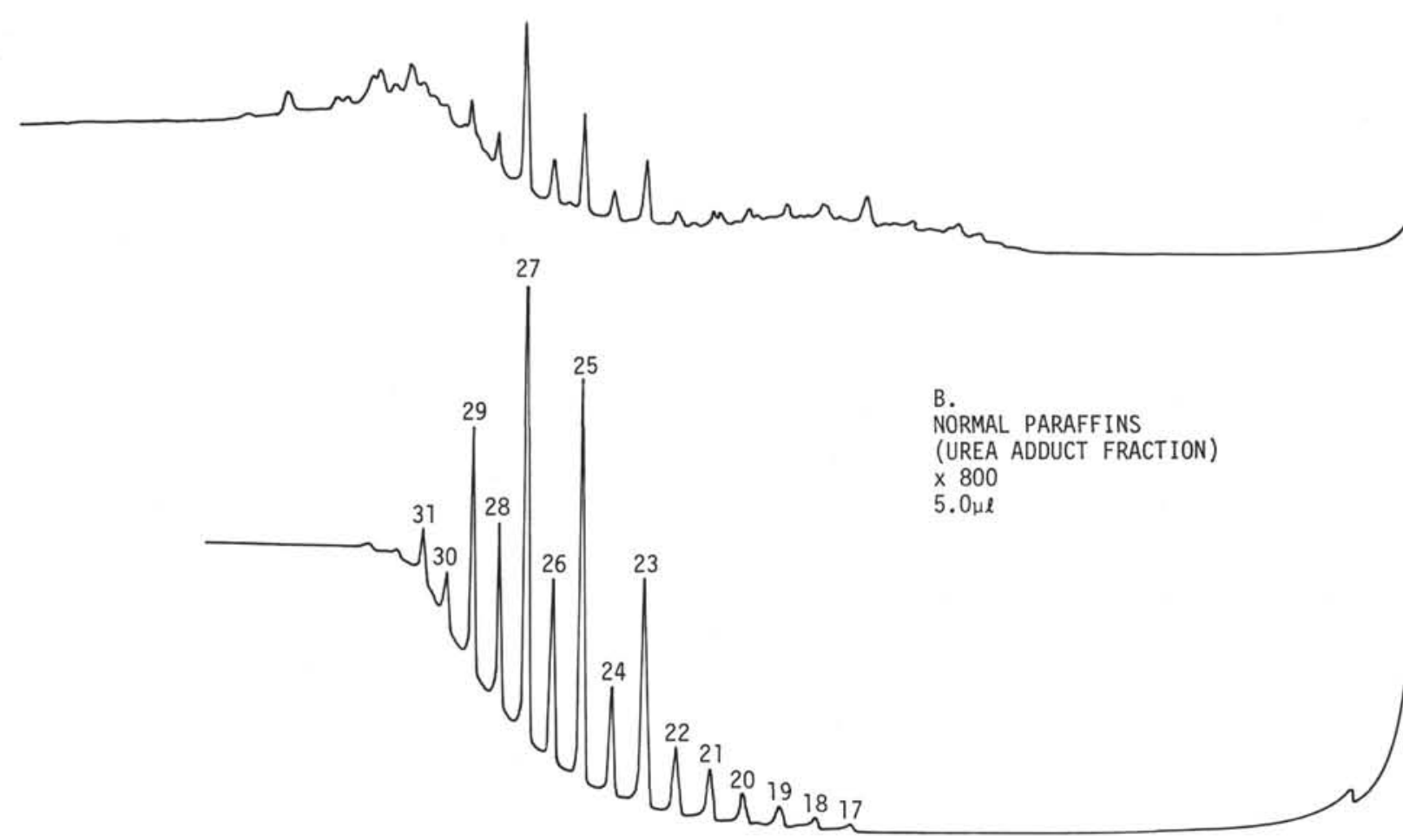

TIME

Figure 2. Representative gas chromatograms, Sample C-1043. Number of carbons per paraffin listed above peaks in B. Increase in background in B due to column bleed. Determinations by B. E. Torkelson. 
TABLE 2

Kerogen Composition

\begin{tabular}{|c|c|c|c|c|c|c|c|c|c|c|}
\hline \multirow[b]{2}{*}{ Sample } & \multirow{2}{*}{$\begin{array}{l}\text { Depth } \\
(\mathrm{m})\end{array}$} & \multicolumn{4}{|c|}{$\begin{array}{l}\text { Normalized Elemental } \\
\text { Composition }(\%)\end{array}$} & \multirow[b]{2}{*}{$\mathrm{H} / \mathrm{C}$} & \multirow[b]{2}{*}{$\mathrm{O} / \mathrm{C}$} & \multicolumn{3}{|c|}{$\begin{array}{l}\text { Visual Classification } \\
\text { Palynomorph Translucency (\%) }\end{array}$} \\
\hline & & $\mathrm{C}$ & $\mathrm{H}$ & $\mathrm{O}$ & $\mathrm{N}$ & & & Morphology & Classopollis & Callialasporites \\
\hline \multicolumn{11}{|l|}{ Site 330} \\
\hline $\begin{array}{l}\text { C- } 1040 \\
\text { C-1041 } \\
\text { C-1042 } \\
\text { C-1043 }\end{array}$ & $\begin{array}{l}315 \\
352 \\
440 \\
525\end{array}$ & $\begin{array}{l}76.7 \\
76.1 \\
75.9 \\
74.7\end{array}$ & $\begin{array}{l}6.5 \\
7.3 \\
6.8 \\
6.5\end{array}$ & $\begin{array}{l}14.5 \\
14.5 \\
15.0 \\
17.6\end{array}$ & $\begin{array}{l}2.3 \\
2.1 \\
2.3 \\
1.2\end{array}$ & $\begin{array}{l}1.01 \\
1.15 \\
1.07 \\
1.04\end{array}$ & $\begin{array}{l}0.14 \\
0.14 \\
0.15 \\
0.18\end{array}$ & $\begin{array}{l}\text { Amorphous } \\
\text { Mixed } \\
\text { Mixed } \\
\text { Structured }\end{array}$ & $\begin{array}{l}47 \\
42 \\
42 \\
42\end{array}$ & $\begin{array}{l}- \\
- \\
-\end{array}$ \\
\hline \multicolumn{11}{|c|}{ Hole $327 \mathrm{~A}$} \\
\hline $\begin{array}{l}\text { C-1241 } \\
\text { C- } 1242 \\
\text { C- } 1243 \\
\text { C-1244 } \\
\text { C-1245 } \\
\text { C-1246 }\end{array}$ & $\begin{array}{l}341 \\
368 \\
396 \\
426 \\
453 \\
463 \\
\end{array}$ & $\begin{array}{c}- \\
- \\
75.7 \\
77.3 \\
72.2 \\
76.6 \\
\end{array}$ & $\begin{array}{l}- \\
- \\
7.5 \\
8.3 \\
7.6 \\
8.2\end{array}$ & $\begin{array}{l}- \\
\overline{-} \\
14.1 \\
12.1 \\
17.5 \\
12.0\end{array}$ & $\begin{array}{l}- \\
- \\
2.7 \\
2.3 \\
2.7 \\
3.2\end{array}$ & $\begin{array}{l}- \\
\overline{-} \\
1.18 \\
1.28 \\
1.26 \\
1.28\end{array}$ & $\begin{array}{l}- \\
\overline{-} \\
0.14 \\
0.12 \\
0.18 \\
0.12\end{array}$ & $\begin{array}{l}\text { Mixed } \\
\text { Mixed } \\
\text { Amorphous } \\
\text { Amorphous } \\
\text { Amorphous } \\
\text { Amorphous }\end{array}$ & $\begin{array}{l}51 \\
47 \\
43 \\
56 \\
57 \\
-\end{array}$ & $\begin{array}{l}-\overline{41} \\
- \\
57 \\
54 \\
44\end{array}$ \\
\hline
\end{tabular}

The $\mathrm{H} / \mathrm{C}$ versus $\mathrm{O} / \mathrm{C}$ diagram (Figure 3 ) provides another indication of the immaturity of the organic matter. Data points for most of the Mesozoic sediments cluster near the horizontal part of the diagenesis track for the type II kerogen of Tissot et al. (1974). A few points lie between the diagenesis tracks of type II and type III kerogens (Figure 3). The horizontal portion of these tracks reflects principally the loss of $\mathrm{CO}_{2}$, and thus represents a stage of diagenesis preliminary to maximum hydrocarbon generation. Type II kerogen follows an $\mathrm{H} / \mathrm{C}-\mathrm{O} / \mathrm{C}$ diagenesis track like that of the coal maceral exinite, and is observed to generate abundant oil (Tissot et al., 1974). Type III kerogen has a diagenesis track comparable to that of vitrinite and generates principally gaseous hydrocarbons (Tissot et al., 1974).

A visual classification of the organic matter contained in these sediments is presented in Table 2. Morphology of the kerogens is somewhat variable, but is mostly amorphous and mixed (Table 2). Sample C1043 from the older interbedded unit contains structured kerogen (Table 2) which would be the terrigenous plant debris described by the DSDP Scientific Staff (1974). The capability of amorphous organic matter to generate relatively large proportions of liquid hydrocarbons is reflected in the moderate to high hydrogen content and the high $\mathrm{H} / \mathrm{C}$ ratios (Table 2). Amorphous kerogens with high concentrations of hydrogen $(>7 \%)$ are believed to indicate a kerogen structure characterized by complex aromatic or cyclic nuclei with long saturated side chains (LaPlante, 1974). Thermal cracking of this type kerogen would yield paraffins characteristic of crude oil.

\section{THERMAL HISTORY}

Although all available data indicate that these sediments are somewhat immature with respect to oil generation, they appear to be overly mature for their present depth of burial ( $525 \mathrm{~m}$ maximum). No downhole temperatures were taken at either site, but a temperature for the deepest sample (C-1043 at $525 \mathrm{~m}$ ) was deduced based on the time-temperature equation of Connan (1974) (Table 3). The organic matter at 525 meters, the deepest and presumably the hottest zone sampled, was concluded to have reached Connan's "threshold of intense oil generation" based on the level of maturity of the kerogen (Table 2), in particular low percent translucency, the $74.7 \% \mathrm{C}$, and the relatively low $\mathrm{H} / \mathrm{C}$ ratio plus the marked increase of total bitumen and the twofold increase in total bitumen/total organic carbon ratio (Table 1). The increase in this ratio is believed to represent the first

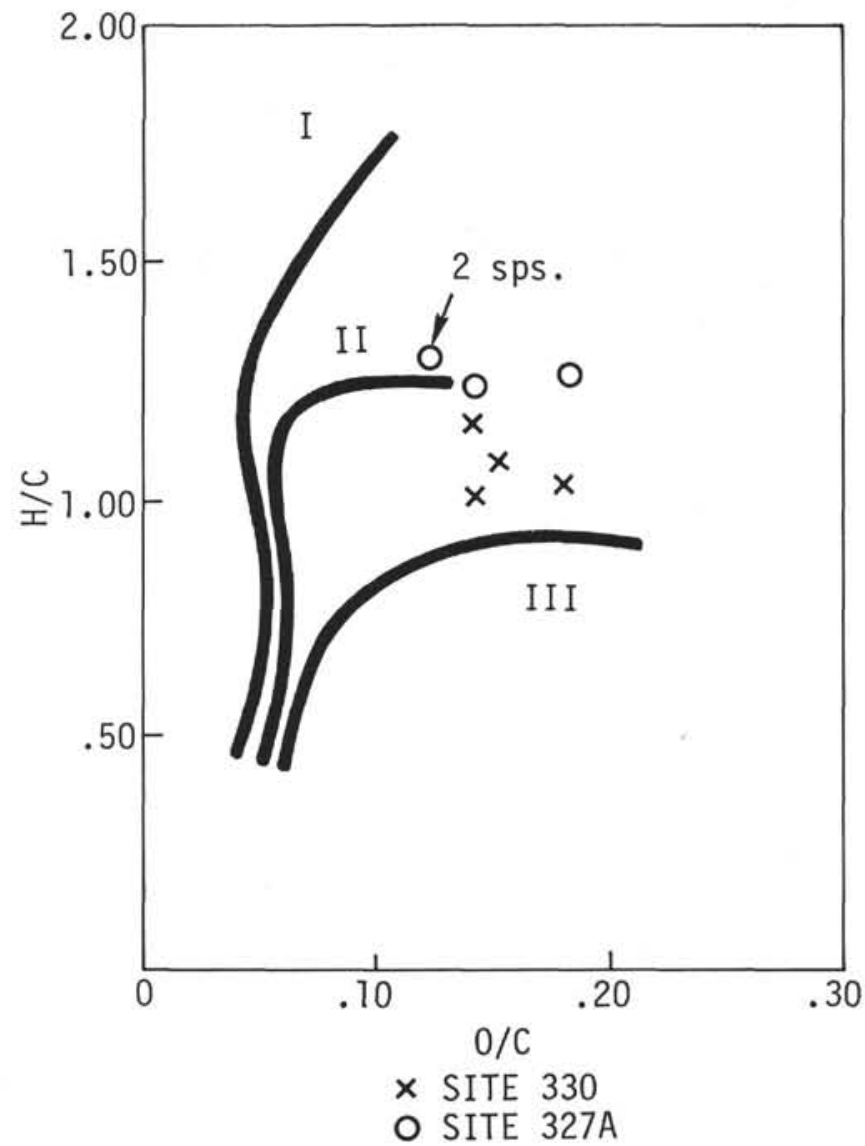

Figure 3. H/C-O/C plot. Heavy lines represent kerogen types I, II, and III of Tissot et al. (1974). 
TABLE 3

Time-Temperature Requirements to Account for Observed Organic Matter Maturity ${ }^{\mathrm{a}}$

\begin{tabular}{|c|c|c|}
\hline $\begin{array}{c}\text { Exposure } \\
\text { Time } \\
\text { (m.y.) }\end{array}$ & Temperature & $\begin{array}{l}\text { Required Thermal Gradient } \\
\text { for } 525 \text { Meter Sample }\end{array}$ \\
\hline $\begin{array}{l}160 \\
100\end{array}$ & $73^{\circ} \mathrm{C}\left(163^{\circ} \mathrm{F}\right)$ & $14^{\circ} \mathrm{C} / 100 \mathrm{~m}\left(7.7^{\circ} \mathrm{F} / 100 \mathrm{ft}\right)$ \\
\hline 100 & $82^{\circ} \mathrm{C}\left(180^{\circ} \mathrm{F}\right)$ & $16^{\circ} \mathrm{C} / 100 \mathrm{~m}\left(8.7^{\circ} \mathrm{F} / 100 \mathrm{ft}\right)$ \\
\hline
\end{tabular}

measurable conversion to oil, and suggests the use of Connan's equation is valid. Hence, if the 525-meter sample has been at that depth for 160 m.y. (the age of this section according to DSDP Scientific Staff, 1974), then a temperature on the order of $73^{\circ} \mathrm{C}$ is required to account for the observed organic matter maturity (Table 3). A temperature of $73^{\circ} \mathrm{C}$ at 525 meters corresponds to a thermal gradient of $14^{\circ} \mathrm{C} / 100 \mathrm{~m}$. For a 60-m.y. shorter exposure time, a $9^{\circ} \mathrm{C}$ higher temperature and a correspondingly higher thermal gradient $\left(16^{\circ} \mathrm{C} / 100 \mathrm{~m}\right)$ are required (Table 3$)$.

These temperatures and thermal gradients are high relative to those from any other sedimentary basin. Using sedimentary thermal gradients more commonly observed, a depth of burial much greater than 525 meters is required to reach the observed maturity (Table 4). The present depth of the 525-meter sample implies erosion of 1500 to 2900 meters of sediment (Table 4) if this area has always had a normal sedimentary thermal gradient. Two major unconformities have been noted in the stratigraphic section at Site 330 by the DSDP Scientific Staff (1974). However, there does not seem to be a long enough time break across either unconformity to allow for erosion of these thicknesses of sediments. The best explanation for the observed level of diagenesis of the organic matter would seem to be both somewhat deeper burial plus a higher thermal gradient sometime during the geologic past. A higher thermal gradient may have arisen in conjunction with tectonic events believed to have occurred in the Falkland Plateau area during Mesozoic time (DSDP Scientific Staff, 1974).

\section{CONCLUSIONS}

The sapropelic claystone occurring at Site 330 and Hole $327 \mathrm{~A}$ is potentially a rich oil source bed. However, this rock unit has not been exposed to sufficient thermal energy for large amounts of oil to be generated. The present depth of burial appears to be too shallow, assuming a reasonable sedimentary thermal gradient, to account for the diagenetic state of the organic matter. These sediments are interpreted both to have been more deeply buried and to have experienced a higher geothermal gradient during the geologic past.

\section{ACKNOWLEDGMENTS}

Samples from the Deep Sea Drilling Project were supplied through the assistance of the National Science Foundation. We are indebted to Amoco Production Company for their cooperation with the analyses and their permission to publish. Analyses were performed by H. Henderson, G. Brown, M. Snoddy, J. McClendon, M. Howarth, B. Torkelson, and R. Littlejohn.

\section{REFERENCES}

Bray, E.E. and Evans, E.D., 1961. Distribution of n-paraffins as a clue to recognition of source beds: Geochim. Cosmochim. Acta, v. 22, p. 2-15.

Connan, J., 1974. Time-temperature relation in oil genesis: Am. Assoc. Petrol. Geol. Bull., v. 58, p. 2516-2521.

DSDP Scientific Staff, 1974. Southwestern Atlantic, Leg 36: Geotimes, v. 19, p. 16-18.

Grayson, J.F., 1975. Relationship of palynomorph translucency to carbon and hydrocarbons in clastic sediments: Colloques International Petrographie de la Matiere Organique des Sediments: Paris (Centre National de la Recherche Scientifique), p. 261-273.

LaPlante, R.E., 1974. Hydrocarbon generation in Gulf Coast Tertiary sediments: Am. Assoc. Petrol. Geol. Bull., v. 58, p. $1281-1289$.

Ronov, A.B., 1958. Organic carbon in sedimentary rocks (in relation to the presence of petroleum): Geochemistry (translation), no. 5, p. 510-536.

Tissot, B., Durand, B., Espitalie, J., and Combaz, A., 1974. Influence of nature and diagenesis of organic matter in formation of petroleum: Am. Assoc. Petrol. Geol. Bull., v. 58, p. $499-506$.

Trask, P.D. and Patnode, H.W., 1942. Source beds of petroleum: Am. Assoc. Petrol. Geol., Tulsa.

TABLE 4

Depth of Burial Required to Account for Observed Organic Matter Maturity

\begin{tabular}{ccc}
\hline Thermal Gradient ${ }^{\mathrm{a}}$ & $\begin{array}{c}\text { Required Depth } \\
\text { of Burial }\end{array}$ & $\begin{array}{c}\text { Thickness of } \\
\text { Sediment Eroded }\end{array}$ \\
\hline $2.7^{\circ} \mathrm{C} / 100 \mathrm{~m}\left(1.5^{\circ} \mathrm{F} / 100 \mathrm{ft}\right)$ & $3400 \mathrm{~m}(11,000 \mathrm{ft})$ & $\sim 2900 \mathrm{~m}(9,400 \mathrm{ft})$ \\
$4.6^{\circ} \mathrm{C} / 100 \mathrm{~m}\left(2.5^{\circ} \mathrm{F} / 100 \mathrm{ft}\right)$ & $2000 \mathrm{~m}(6,500 \mathrm{ft})$ & $\sim 1500 \mathrm{~m}(4,800 \mathrm{ft})$ \\
\hline
\end{tabular}

\footnotetext{
${ }^{\text {a }}$ Range of gradients for sedimentary basins (e.g., Connan, 1974).
} 